tive and international audience all over Great Britain, showing in the most exquisite photography different types of landscapes and the birds that are found there: from a typical English garden to the moors and mountains of Scotland, the Lake District, wood. lands, fields and hedgerows, the fens, sandy shores and rocky coasts-a film which indeed demonstrates the glories of Britain to the foreigner and should justly make any Briton proud. About thirty species of birds were represented, all of such beauty that it is difficult to make any special mention, but the shots of a shelduck feeding in a shallow pool and reflected in the water are perhaps the highest achievement gained by any Nature photographer. The Belgian Ambassador, in moving a vote of thanks to $\mathrm{Mr}$. Higham, stressed the value of international cooperation in Nature preservation; he mentioned in particular the International Conference on the Preservation of the Fauna of Africa and the proposed conference for the preservation of the fauna of the Pacific, which had to be abandoned on the outbreak of war.

\section{A Part-time Education Scheme}

WE have received a copy of an illustrated booklet which is handed to every boy on entering the service of W. T. Henley's Telegraph Works Co., Ltd., and Henley's Tyre and Rubber Co., Ltd. This booklet outlines a scheme which is intended to enable all youths joining the Henley organization to see how they can train themselves for their careers. Every boy is given the option of undertaking a course of training extending over a period of years. 'Those who have shown that they can benefit from such privileges and have been accepted for the course are released one day a week from their normal works duties to attend approved classes at selected educational institutions near to their place of employment. They are expected to devote themselves wholeheartedly to the courses laid down for them during this day, and to attend a recognized educational establishment of their own choosing on at least one other evening in the week, for which purpose, wherever practicable, they will be released from shift-work or overtime. In addition, they must undertake to carry cut the homework in connexion with their day course to the satisfaction of the education authorities. The subjects selected for the day periods are of a more serious and fundamental nature, but a good deal of freedom is given in the selection of subjects for the evening courses. Boys are paid for the time spent at the day establishment, and all fees, both for the day and evening courses, are paid by Henley's. The scheme is intended to produce better workmen, foremen and managers, and also better citizens; in addition to every encouragement being given to the boys to enlarge their mental outlook, physical training classes form an important part of the scheme.

\section{Production of Crop Seeds}

THE supply and distribution of seeds of agricultural and horticultural crops has been a problem of major concern since 1939 for countries isolated from Central Europe. The developments that have taken place in their attempt to achieve self-sufficiency in this respect are described in Joint Publication No. 5 issued by the Imperial Bureaux, "The Production of Seed of Root Crops and Vegetables" (price 3s.). The creation of the sugar beet industry in the United States market is perhaps the most complete of the accounts published, for it ean now meet domestic needs, whereas during 1932-34 dependence on imported seed was absolute. Good results have been obtained with vegetable seed production in Sweden, and provided the right areas are selected the prospect seems promising in Australia, New Zealand and Canada. As regards Great Britain considerable progress has been made, and although Scotland appears to be outside the limits of economic seed production for all but a few vegetable crops, in England the chief advances lie in determining those areas where maximum seed yield can be expected. An interesting development is the investigation into the possibilities afforded by the tropical highlands and by those parts of the Empire which lie in the Mediterranean basin. Much information is provided on the varieties used, seed laws and regulations, and a useful index of crops and varieties is appended. Specialists or members of recognized scientific institutions who are in need of more complete references to the literature on any given section, or of more detailed information on special points, are invited to apply to the Imperial Agricultural Bureaux at East Malling, Aberystwyth or Cambridge.

\section{Earthquakes in Central and South America}

The United States Coast and Geodetic Survey, in co-operation with Science Service and the Jesuit Seismological Association, has found the epicentres of three recent earthquakes in Central and South America. The first, on June 30, occurred at $20 \mathrm{~h}$. $13.0 \mathrm{~m}$. U.T. from an epicentre near lat. $14 \cdot 5^{\circ} \mathrm{S}$., long. $74^{\circ} \mathrm{W}$., which is just north of the town of Coracora in Peru. The focus may have been deeper than normal. The second, on July 4 , occurred at $9 \mathrm{~h} .52 \cdot \mathrm{lm}$. U.T. from an epicentre near lat. $9^{\circ}$ N., long. $84 \cdot 5^{\circ} \mathrm{W}$., which is near the coast south-east of the town of San José, and due south of the volcano Irazu in Costa Rica. The depth of focus in this instance was possibly $100 \mathrm{~km}$. The third earthquake was on July 5 at $2 \mathrm{Ih}$. $7 \cdot 6 \mathrm{~m}$. U.T. from an epicentre lat. $17 \cdot 5^{\circ} \mathrm{S}$., long. $73^{\circ} \mathrm{W}$., which is immediately off the coast west of the town of Mollendo in Peru. The depth of focus was normal. All these epicentres are in well-known seismic areas and all interpretations and determinations are tentative. Calculations were based on instrumental reports from the seismological observatories at Georgetown, Weston, St. Louis, Pasadena, Philadelphia, Fordham, Tucson, San Juan, Washington D.C., Burlington, Mobile, Buffalo, and Salt Lake City.

\section{Parsons Memorial Lecture}

The Parsons Memorial Fund, which is administered by the Royal Society, made provision for a memorial to the late Hon. Sir Charles Parsons in Westminster Abbey, and for an annual Parsons Lecture to be given under the auspices of eight specified institutions and societies in turn which are concerned with the subjects most closely associated with Parsons' name. In accordance with the terms governing the appoint. ment of the lecturers, the 1943 lecture, which is the eighth of the series, is to be given under the auspices of the Physical Society. It will be delivered at the meeting of the Society at the Royal Institution at 4.30 p.m. on October 15, by the Right Hon. Lord Rayleigh, who has chosen as his subject "Optical Topics, in part connected with Charles Parsons". Previous lectures have dealt more especially with other aspects of Parsons' work. 